\title{
Evaluation of anise (Pimpinella anisum L.) accessions with regard to morphological characteristics, fruit yield, oil contents and composition
}

\author{
Habib Ullah ${ }^{1,2 \star}$, Athar Mahmood ${ }^{3}$, Muhammad ljaz $^{4}$, B. Tadesse $^{1}$ and B. Honermeier ${ }^{1}$ \\ ${ }^{1}$ Institute of Agronomy and Plant Breeding I, Justus Liebig University Giessen, Ludwigstrasse 23, \\ Giessen D-35390, Germany. \\ ${ }^{2}$ University College of Agriculture, Bahauddin Zakarriya University Multan, Pakistan. \\ ${ }^{3}$ University College of Agriculture, University of Sorgodha, Pakistan. \\ ${ }^{4}$ University College of Agriculture, Islamia University Bhawalpur, Pakistan.
}

Accepted 19 June, 2013

\begin{abstract}
A field experiment was carried out to determine morphological characteristics, fruit yield, oil contents and composition of accessions of anise (Pimpinella anisum L.) during 2007 to 2008. A total of fifteen accessions were studied: (1) 15104614 Martin Bauer; (2) 15104893 Martin Bauer; (3) 16101709 Martin Bauer; (4) 16103904 Martin Bauer; (5) 16104662 Martin Bauer; (6) N. L. Chrestensen Erfurt; (7) Hild; (8) Izmir Turkey; (9) Cultivar 903 Nebelung; (10) Cultivar 904 Nebelung; (11) Pharmasaat; (12) Quedlinburg; (13) Enza Zaden Nederland; (14) Heil-Z Aussaatrest 07 Landwirt Heil; (15) Heil-nB Aussaatrest 07 Landwirt Heil. The maximum number of primary branches and umbels per plant were produced by 15104614 Martin Bauer, 16103904 Martin Bauer and N. L. Chrestensen Erfurt, whereas, Heil-Z Aussaatrest 07 Landwirt Heil produced the lowest number of primary branches and umbels per plant in 2008. A greater number of primary branches and umbels per plant were observed in the year 2007, compared with 2008, for any accession, suggesting the independency of accessions. Current trials showed that a higher infection rate with Cercospora malkoffii was estimated in accessions (1: 15104614 Martin Bauer, and 8: Izmir Turkey) in both seasons. The highest fruit yields of 0.47 and $0.46 \mathrm{t} \mathrm{ha}^{-1}$ were noticed in accessions (15: Heil-B Aussaatrest 07 Landwirt Heil and 2: 15104893 Martin Bauer), respectively, in 2007, whereas the lowest values were observed with accessions (1: 15104614 Martin Bauer, 3: 16101709 Martin Bauer, 7: Hild and 8: Izmir Turkey) in 2007. In current trials, maximum oil content was obtained in accessions $2,11,15$ and $5,11,13$ whereas the lowest concentration was determined in accessions 1, 3, 7 and 3, 4, 7 in 2007 and 2008, respectively. The major constituent in the essential oil of the tested accession fruits was found to be a phenylpropanoid, namely trans-anethole, which ranged from 82.9 to 90.9 and 90.5 to 95.7 in 2007 and 2008, respectively. The highest level of trans-anethole was noted in accessions 3, 7 and 8 . Current results demonstrate that availability of various accessions provides the opportunity for anise production to meet the market requirement.
\end{abstract}

Key words: Accessions, anise, fruit yield, estragol, trans-anethole.

\section{INTRODUCTION}

Anise (Pimpinella anisum L.) is an annual important spice and medicinal plant belonging to the family Apiaceae and is considered as a natural raw material and used for pharmaceutics, perfumery, food and cosmetic industries 
(Omidbaigi et al., 2003; Ross, 2001). In recent times, this that is native to the Mediterranean region. Today, anise spice plant has attracted consumer attention due to its antimicrobial, antifungal, insecticidal, and antioxidative effect on human health (Gülcin et al., 2003; Knio et al., 2008; Kosalec et al., 2005; Shukla and Tripathi, 1987; Tunc and Sahinkaya, 1998). The drug, as well as the essential oil, is characterized by carminative, mild expectorant, diuretic, antiseptic, and antispasmodic effects (Bown, 2001).

The quality of anise is determined mainly by its essential oil content and composition. For both quality parameters, it is necessary to determine the environmental factors under which they give higher yields and better quality (Omidbaigi, 2000). Anise fruits, called aniseed, contain around 1.5 to $5.0 \%$ essential oil, which is composed of more than $90 \%$ volatile phenylpropanoids like trans-anethole followed by $\mathrm{y}$-himachalene, methyl chavicol (estragol), anisaldehyde, $\beta$-himachalene and $\alpha$ zingiberene (Omidbaigi et al., 2003; Tabanca et al., 2005). The yield and essential oil content may considerably vary depending on the environmental conditions and genetic potential of the crop (Orav et al., 2008; Zheljazkov et al., 2008). In this context, there are reports showing the effects of row spacing, water supply, fertilization, sowing time, and sowing density on anise yield and quality under field and greenhouse conditions (Awad et al., 2005; Maheshwari et al., 1999; Tuncturk and Yildirim, 2006; Zehtab-salmasi et al., 2001). In European countries consumption of anise fruits is greater than its production, leading to an imported quantity of anise fruits of almost $2000 \mathrm{t}$ in 2004 (Bown, 2001). This has led to a high demand to cultivate anise crop in European countries including Germany. However, the anise plant is not native to Germany, but the climatic conditions are generally suitable for its cultivation (Heeger, 1956).

Since anise favors warm climatic conditions throughout the growing season, it is cultivated in particularly subtropical regions (Reineccius, 1994; Hänsel et al., 1999). Anise cultivated fields should be protected from wind to save the plants from lodging (Ebert, 1982; Poss, 1991). The reported life zone for anise cultivation is 8 to $23^{\circ} \mathrm{C}$ with 1,000 to $1,200 \mathrm{~mm}$ annual precipitation, this produces excellent crop, however a rainfall of $2,000 \mathrm{~mm}$ is tolerated with a soil $\mathrm{pH}$ of the cultivated field ranging from 6.3 to 7.3 (Simon et al., 1984). The temperature during the growing duration should be quite uniform without very hot periods, particularly following precipitation. Relative studies of a large number of genotypes of anise ( $P$. anisum L.) in Germany are few. There is a significant interest in anise as a prospective high value essential oil crop in the European countries; though, there are no reports on anise productivity, essential oil content, and composition in this region. The hypothesis of this study was that certain anise genotypes might be better suited to grow in Germany's climatic conditions as a high value essential oil crop.

\section{MATERIALS AND METHODS}

\section{Experiment design and site description}

The field experiment was conducted at the Gross-Gerau research station, Germany $\left(49^{\circ} 45^{\prime} \mathrm{N}\right.$ and $8^{\circ} 29^{\prime} \mathrm{E}, 90.7 \mathrm{~m}$ above sea level in sandy soil where the mean air temperature is $9.4^{\circ} \mathrm{C}$ and mean precipitation is $590 \mathrm{~mm} /$ year; Source: metrological station at experimental station Gross-Gerau). The monthly average air temperature and sum of precipitation for the growing seasons 2007 to 2008 are presented in Figure 1. The soils are described as slightly loamy to loamy sand consistency, characterized by the following parameters: clay content $5 \%(0$ to $30 \mathrm{~cm}), \mathrm{pH} 6.4$, available field capacity $<100 \mathrm{~mm}(0$ to $100 \mathrm{~mm})$, with nutrient measures of $\mathrm{P}: 9.2 \mathrm{mg} / 100 \mathrm{~g}, \mathrm{~K}: 12.9 \mathrm{mg} / 100 \mathrm{~g}$ and $\mathrm{Mg}: 2.0$ $\mathrm{mg} / 100 \mathrm{~g}$ of soil. A total of fifteen $P$. anisum $\mathrm{L}$. were studied: (1) 15104614 Martin Bauer; (2) 15104893 Martin Bauer; (3) 16101709 Martin Bauer; (4) 16103904 Martin Bauer; (5) 16104662 Martin Bauer; (6) N.L. Chrestensen Erfurt; (7) Hild; (8) Izmir Turkey; (9) Cultivar 903 Nebelung; (10) Cultivar 904 Nebelung; (11) Pharmasaat; (12) Quedlinburg; (13) Enza Zaden Nederland; (14) Heil-Z Aussaatrest 07 Landwirt Heil; and (15) Heil-nB Aussaatrest 07 Landwirt Heil, were obtained from the Institute of Plant Genetics and Crop Plant Research (IPK), Gatersleben in Germany. All the accessions were evaluated for their fruit yield, essential oil content and composition in two consecutive years during April, 2007 and 2008 in a randomized block design with four replications.

The seed rate of $1 \mathrm{~g} \mathrm{~m}^{-2}$ was used to achieve a plant population of 200 plants $\mathrm{m}^{-2}$ to achieve the highest fruit yield (Ullah and Honermeier, 2013). Individual research plots were $1.5 \mathrm{~m} \times 7 \mathrm{~m}$, having eight rows with row spacing of $18.7 \mathrm{~cm}$. Land preparations was accomplished by chisel plowing in the fall and cultivated twice in the spring prior to sowing the anise crop. Before seeding, fields were disked and harrowed, and fertilizer was added to provide 31 $\mathrm{kg} \mathrm{ha}^{-1} \mathrm{P}, 174 \mathrm{~K} \mathrm{~kg} \mathrm{ha}^{-1}$ in accordance with soil analysis and the fertilizer requirement of the crop in the both years. The nitrogen content $\left(\mathrm{NO}_{3}-\mathrm{N}, \mathrm{NH}_{4}-\mathrm{N}\right)$ in the soil $(0$ to $90 \mathrm{~cm})$ was $52 \mathrm{~kg}$ in both years 2007 and 2008. After germination of anise, $40 \mathrm{~kg} \mathrm{~N} \mathrm{ha}^{-1}$ $\left(\mathrm{NH}_{4} \mathrm{NO}_{3}+\mathrm{CaCO}_{3}\right)$ was applied in both seasons.

Fungicides of RADOMIL GOLD-M (active ingredient: $40 \mathrm{~g} / \mathrm{kg}$ Metalaxyl-M $+800 \mathrm{~g} / \mathrm{kg}$ Mancoze manufactured by Syngenta Crop Protection AG, Basel, Switzerland) and SCORE (active ingredient: Difenoconazol; manufactured by Syngenta Group Company) were applied at a rate of $2 \mathrm{~kg} \mathrm{ha}^{-1}$ and $0.4 \mathrm{~L} \mathrm{ha}^{-1}$, respectively by hand boom-sprayer equipped with Tee-Jet nozzles before flowering. Weed control was either carried out by application of herbicide, Bandur (Aclonifen) with $3 \mathrm{~L} \mathrm{ha}^{-1}$ or by hand pulling. Plants were irrigated 3 times $(20,20$ and $20 \mathrm{~mm})$ in 2007 and three times $(10$, 20 and $20 \mathrm{~mm}$ ) in 2008 according to irrigation requirements. The anise crop was sown in the first week of April during both years. The harvesting was done on 18th and 10th August during 2008 and 2009, respectively.

\section{Morphological and yield components}

Morphological parameters were analyzed as done by Yan et al. (2011), by analyzing samples of anise plants from two rows $(2 \mathrm{~m}$ length) in the middle of the plot. With these plant samples, the following yield components were determined: number of primary branches/plant (PBP), number of umbels/plant (NUP), number of fruits/plant (NFP), fruit weight/plant (FWP) and 1,000 fruit weight (TFW). Prior to harvesting, plant height was measured with a yardstick. The TFW was accomplished by counting each sample twice using an automated seed counter (Contador) and averages worked out. A combine harvester was used to reap the harvest when the fruit was completely ripe (at $90 \%$ DM contents). Fruit from each plot was stored in the harvester bin and weighed in $\mathrm{kg}$ per plot 


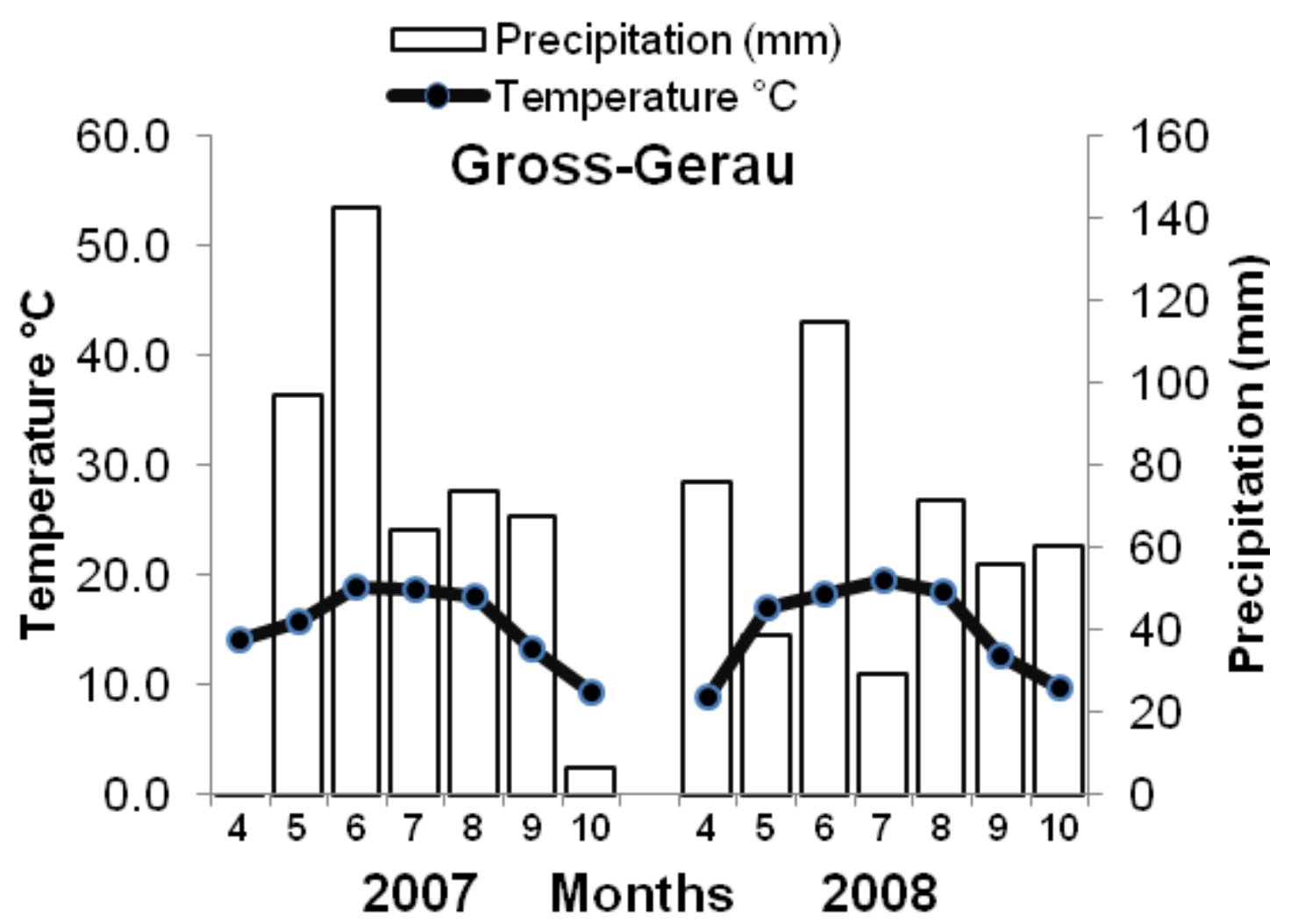

Figure 1. Monthly average air temperature $\left({ }^{\circ} \mathrm{C}\right)$ and monthly sum of precipitation $(\mathrm{mm})$ for the growing seasons (from April to October) of 2007 and 2008 at the experimental station Gross-Gerau (Germany).

and then converted to a tons per hectare basis. During plant growth, a fungal disease was observed on the anise accessions in both years. Fungal disease incidence (FDI) on anise plants was assessed (identified by visual symptoms) on a 1 to 9 grading scale (1: without infection, 9: whole plants were infected). Lodging was also estimated similarly by grading 1 to 9 (1: erect plants, 9: whole plants were lodged).

\section{Essential oil extraction}

Fruit samples $(7 \mathrm{~g})$ of each plot were hydro-distilled for $2 \mathrm{~h}$ using a Clevenger-type apparatus according to the European pharmacopoeia (European Pharmacopoeia, 2000) (EP). The essential oil content was quantified gravimetrically. Each sample was analyzed twice and the average of both was used for further statistic evaluation. The essential oil concentration was calculated as the amount $(\mathrm{g})$ of oil per weight $(\mathrm{g})$ of dry anise tissue, while the oil yield per area was calculated from the fruit yields per area and oil content of every anise accession and replicate. The obtained essential oil was kept at $4^{\circ} \mathrm{C}$ for further lab analyses.

\section{Gas chromatography (GC) and gas chromatography-mass} spectrometric (GC-MS) analyses

The components of the essential oil were analyzed by gas chromatography-flame ionization detector (GC-FID) (Varian CP $3800)$, capillary column DB-5 $(30 \mathrm{~m} \times 0.25 \mathrm{~mm}$ and $0.25 \mu \mathrm{m}$ coating thickness) as described by Yan et al. (2011). Helium was employed as the carrier gas with a flow rate of $1.1 \mathrm{ml} / \mathrm{min}$. The temperature was programmed from $60^{\circ} \mathrm{C}(5 \mathrm{~min})$ to $250^{\circ} \mathrm{C}$ with a ramp rate of $5^{\circ} \mathrm{C} / \mathrm{min}$, and a final hold time of $10 \mathrm{~min}$. Injector and detector were maintained at 260 and $280^{\circ} \mathrm{C}$, respectively. The sample $(1 \mu \mathrm{l})$ was injected with a 1:50 split ratio by an autosampler (Varian $8200 \mathrm{CX}$ ). The percentage of individual components was computed from peak areas. The response factors of the detector and FID normalization were considered for data processing. The identification of the components was carried out by GC-MS (Varian 3900 GC, Varian Saturn $2100 T$ ion trap mass detector), capillary column VF-5ms (30 $\mathrm{m} \times 0.25 \mathrm{~mm}, 0.25 \mu \mathrm{m}$ coating thickness). Helium was used as a carrier with a flow rate of $1.1 \mathrm{ml} / \mathrm{min}$. Ionization was realized by electron impact at $70 \mathrm{eV}$, electron multiplier $2200 \mathrm{~V}$, ion source temperature $230^{\circ} \mathrm{C}$ and transfer line temperature $240^{\circ} \mathrm{C}$. Mass spectral analysis was acquired in the scan mode in the $\mathrm{m} / \mathrm{z}$ range 35 to 450 . The identification of components was based on a comparison of Kovat's retention indices and mass spectra in corresponding data libraries (Adams, 1995; Özcan and Chalchat, 2006) and mass spectra libraries (Weily 90 and NIST 98). Kovat's retention indices were calculated from the $\mathrm{GC}$ by linear interpolation between bracketing n-alkanes (C8-C24; Alfa Aesar Karlsruhe, Germany). The most important components, trans-anethole and estragol were further identified by co-injection of authentic standards (Roth, Karlsruhe, Germany).

\section{Statistical analyses}

Data was subjected to statistical analysis by using the statistical program "PIAFStat" (Planning information analysis program) for checking the significance of the different treatments, whereas least significant difference (LSD) at $5 \%$ probability level was used for 
studying the difference between different experimental treatments. Correlation analysis was performed by statistical package for social sciences (SPSS) (SPSS, Chicago, USA) to determine the relationship among the studied parameters according to Pearson's and Spearman's rho method.

\section{RESULTS AND DISCUSSION}

\section{Lodging and fungal disease incidence}

Lodging rate was estimated before harvesting, and during this experiment its value ranged from 1.0 to 7.0 in both seasons. Higher lodging was observed in 2007 compared to 2008, which might be due to taller anise plants and adverse environmental conditions. Severe lodging in plants during fruit initiation may prevent the transport of water, nutrients and assimilates through the xylem and phloem, resulting in reduced assimilates for grain filling and premature fruit formation. High moisture levels in a lodged plant population may be favorable for fungal growth and for the development of diseases, which have detrimental effects on plant growth and fruit quality of anise plants. As it's clear from Table 1, disease infection at maturity reached a level of 2.8 to 7.3 and 5.3 to 9.0 in 2007 and 2008, respectively. In 2007, severe infection of Cercospora malkoffii was observed in accession 8 compared with other accessions, whereas a lower infection rate was noticed in accession 2 and accession 15. In 2008, a higher level of $C$. malkoffii was recorded in accessions 1 and 8 . Among the evaluated accessions, 9, 11,14 and 15 had a similar level of infection in 2008 (Table 1). In 2008, a higher germination rate was observed, which could be contributed to higher FDI compared with 2007.

\section{Morphological parameters and fruit yield components}

Plant height varied significantly among the 15 accessions evaluated and ranged from 28 to $61 \mathrm{~cm}$ in both seasons (Table 2). Overall, taller anise plants were observed in 2007 compared with 2008, because anise plants received higher precipitation during the vegetative stage in 2007 (304 mm, May to July) compared with 2008 (184 mm). Furthermore, the lower germination rate during 2007 might have influenced plant height, causing the plant to use the more readily available resources more efficiently (water, nutrients, light) and consequently produce taller anise plants. 15104614 Martin Bauer and Izmir Turkey accessions were recorded as the (significantly) shortest plant height in both seasons. The significant variation with respect to plant height among the accessions might be due to different genetic characteristics. Moreover, a higher infection rate with these accessions during the shooting stage badly affected photosynthetic activity and produced smaller plants.

Plant height of anise significantly correlated with fruit yield $(r=0.398)$ and $(r=0.662)$ in 2007 and 2008, respectively. The yield contributing parameters, including PBP, NUP, NFP, and FWP were not affected in 2007, whereas significant differences were observed among tested accessions in 2008. The number of primary branches and umbels per plant ranged from 2.4 to 5.6 and 3.4 to 12.9, in 2007 and 2008, respectively. Similar results have been reported previously (Tuncturk and Yildirim, 2006; Yan et al., 2011). The maximum number of primary branches and umbels per plant were recorded in 15104614 Martin Bauer, 16103904 Martin Bauer and N.L. Chrestensen Erfurt, whereas, Heil-Z Aussaatrest 07 Landwirt Heil produced the lowest number of primary branches and umbels per plant in 2008. A higher number of primary branches and umbels per plant were observed in the year 2007 compared with 2008. The anise plants grown in 2007 received more precipitation with $445 \mathrm{~mm}$ compared with $312 \mathrm{~mm}$ (in 2008) during the vegetative stage, which enhanced the yield contributing parameters. Alternatively, the plants grown in the year 2008 might have been heavily infected by the fungus $C$. malkoffii (infection level: 2.8 to 7.3 in the year 2007 and 5.3 to 9.0 in the year 2008), which infects all above parts of the plants (including leaves, flowers, stems and fruits) and that would have limited the photosynthetic surface area of anise plants. The higher fungal infection in 2008 could additionally have reduced the formation of side branches and inflorescence of anise plants during that year.

In the current study, primary branches were positively and significantly correlated with the number of umbels $(r$ $=0.895)$ and $(r=0.840)$ in 2007 and 2008, respectively (Table 4). In 2007, all tested accessions showed similar results regarding fruit number and fruit weight per plant, whereas a remarkable variation was noticed in 2008. However, in the current study, the NFP and FWP ranged from 17 to $136,0.04$ to 0.47 and from 19 to $115,0.05$ to 0.33 in 2007 and 2008, respectively. The present results are in accordance with previous findings by Yan et al. (2011) who executed field experiments with anise cultivar 903 under field conditions in Germany and reported a similar number of branches, umbels and fruits per plant that ranged from 5.6, 8.4 and 210 , respectively. A higher infection rate with $C$. malkoffii was registered in accessions (1: 15104614 Martin Bauer, 8: Izmir Turkey) in both seasons whereas a higher lodging rate was recorded in similar accessions in 2007.

Severe lodging in plants during fruit initiation may prevent the transport of water, nutrients and assimilates through the xylem and phloem, resulting in a reduction in assimilates for grain filling and premature fruit formation, which results in reduced fruit weight per plant. Higher moisture levels in a lodged plant population may be favorable for fungal growth and for the development of diseases, which have detrimental effects on plant growth and fruit quality of anise plants. The higher infection of $C$. malkoffii prevailed in accession 8: Izmir Turkey, which might be due to the transmission of pathogens by seeds. 
Table 1. Effect of lodging (1-9) and fungal disease incidence (1-9) on performance of anise at Gross-Gerau 2007-2008

\begin{tabular}{|c|c|c|c|c|c|c|c|c|c|c|c|c|c|c|c|c|}
\hline \multicolumn{17}{|c|}{ Field evaluations 2007} \\
\hline Parameter & Unit & 1 & 2 & 3 & 4 & 5 & 6 & 7 & 8 & 9 & 10 & 11 & 12 & 13 & 14 & 15 \\
\hline Lodging & $1-9$ & $4.0 \pm 0.0$ & $2.8 \pm 0.96$ & $5.3 \pm 0.50$ & $2.0 \pm 0.00$ & $2.0 \pm 0.00$ & $3.5 \pm 0.58$ & $7.0 \pm 0.00$ & $7.0 \pm 0.00$ & $2.0 \pm 0.00$ & $2.3 \pm 0.50$ & $2.8 \pm 0.70$ & $2.8 \pm 0.50$ & $3.0 \pm 1.00$ & $2.5 \pm 0.58$ & $2.3 \pm 0.50$ \\
\hline Fungal disease incidence & $1-9$ & $5.0 \pm 2.00$ & $2.8 \pm 0.96$ & $4.0 \pm 0.00$ & $4.8 \pm 0.50$ & $3.3 \pm 0.50$ & $4.3 \pm 0.96$ & $4.5 \pm 1.00$ & $7.3 \pm 0.96$ & $4.0 \pm 0.82$ & $5.0 \pm 1.83$ & $4.8 \pm 0.96$ & $3.8 \pm 1.50$ & $4.8 \pm 0.96$ & $3.8 \pm 0.50$ & $3.0 \pm 1.1$ \\
\hline \multicolumn{17}{|c|}{ Field evaluations 2008} \\
\hline Lodging & $1-9$ & $1.0 \pm 0.00$ & $1.0 \pm 0.00$ & $1.8 \pm 0.50$ & $1.0 \pm 0.00$ & $1.0 \pm 0.00$ & $1.0 \pm 0.00$ & $3.0 \pm 0.82$ & $1.0 \pm 0.00$ & $1.0 \pm 0.00$ & $1.0 \pm 0.00$ & $1.0 \pm 0.00$ & $1.5 \pm 0.58$ & $1.0 \pm 0.00$ & $1.0 \pm 0.00$ & $1.0 \pm 0.00$ \\
\hline Fungal disease incidence & $1-9$ & $9.0 \pm 0.00$ & $6.3 \pm 0.96$ & $6.5 \pm 0.58$ & $6.5 \pm 1.00$ & $5.3 \pm 0.50$ & $6.0 \pm 1.1$ & $6.8 \pm 0.50$ & $9.0 \pm 0.00$ & $7.0 \pm 0.00$ & $6.3 \pm 0.50$ & $7.5 \pm 0.58$ & $5.5 \pm 0.58$ & $6.8 \pm 0.50$ & $7.3 \pm 0.50$ & $7.0 \pm 0.00$ \\
\hline
\end{tabular}

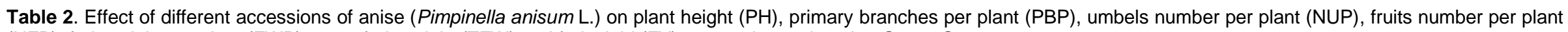
(NFP), fruit weight per plant (FWP), 1000-fruit weight (TFW) and fruit yield (FY) at experimental station Gross-Gerau 2008.

\begin{tabular}{|c|c|c|c|c|c|c|c|c|c|c|c|c|c|c|c|c|c|}
\hline \multicolumn{18}{|c|}{2007} \\
\hline Para. & Unit & 1 & 2 & 3 & 4 & 5 & 6 & 7 & 8 & 9 & 10 & 11 & 12 & 13 & 14 & 15 & $\begin{array}{c}\text { LSD } \\
5 \%\end{array}$ \\
\hline $\mathrm{PH}$ & $\mathrm{cm}$ & $29 \pm 2.7$ & $59 \pm 3.1$ & $55 \pm 3.3$ & $49 \pm 4.4$ & $59 \pm 1.9$ & $52 \pm 4.3$ & $54 \pm 2.7$ & $37 \pm 1.0$ & $61 \pm 1.5$ & $61 \pm 3.5$ & $58 \pm 3.8$ & $56 \pm 4.1$ & $59 \pm 2.5$ & $61 \pm 1.4$ & $56 \pm 3.8$ & 4.6 \\
\hline PBP & No. & $4.9 \pm 0.1$ & $5.1 \pm 0.7$ & $4.3 \pm 0.2$ & $4.5 \pm 0.7$ & $5.3 \pm 0.3$ & $4.0 \pm 0.4$ & $5.3 \pm 0.6$ & $4.1 \pm 0.6$ & $5.4 \pm 0.7$ & $4.9 \pm 1.1$ & $4.3 \pm 0.9$ & $4.9 \pm 0.5$ & $5.1 \pm 1.8$ & $5.1 \pm 1.5$ & $5.2 \pm 1.0$ & ns \\
\hline NUP & No. & $10.3 \pm 1.5$ & $10.9 \pm 2.2$ & $8.0 \pm 0.7$ & $10.7 \pm 3.8$ & $10.2 \pm 1.1$ & $7.4 \pm 2.2$ & $10.9 \pm 1.1$ & $7.8 \pm 2.2$ & $10.9 \pm 2.6$ & $7.8 \pm 2.4$ & $7.6 \pm 2.9$ & $10.4 \pm 2.3$ & $10.9 \pm 6.3$ & $10.1 \pm 3.9$ & $10.4 \pm 3.4$ & ns \\
\hline NFP & No. & $92 \pm 20$ & $102 \pm 35$ & $37 \pm 14.2$ & $115 \pm 73$ & $60 \pm 31$ & $93 \pm 29$ & $42 \pm 28$ & $31 \pm 31$ & $75 \pm 30$ & $17 \pm 12$ & $87 \pm 25$ & $121 \pm 18$ & $30 \pm 24$ & $68 \pm 34$ & $136 \pm 22$ & ns \\
\hline FWP & $\mathrm{g}$ & $0.12 \pm 0.02$ & $0.20 \pm 0.03$ & $0.16 \pm 0.07$ & $0.20 \pm 0.02$ & $0.11 \pm 0.05$ & $0.47 \pm 0.07$ & $0.06 \pm 0.05$ & $0.05 \pm 0.06$ & $0.13 \pm 0.02$ & $0.04 \pm 0.02$ & $0.17 \pm 0.03$ & $0.28 \pm 0.04$ & $0.05 \pm 0.01$ & $0.13 \pm 0.05$ & $0.29 \pm 0.02$ & ns \\
\hline TFW & $g$ & $1.31 \pm 0.14$ & $1.65 \pm 0.15$ & $2.08 \pm 0.33$ & $1.88 \pm 0.09$ & $2.19 \pm 0.2$ & $2.34 \pm 0.41$ & $2.53 \pm 0.41$ & $1.95 \pm 0.14$ & $2.23 \pm 0.4$ & $2.03 \pm 0.2$ & $1.89 \pm 0.3$ & $2.48 \pm 0.12$ & $2.13 \pm 0.14$ & $1.87 \pm 0.2$ & $2.12 \pm 0.16$ & 0.34 \\
\hline FY & dtha-1 & $1.4 \pm 0.5$ & $4.6 \pm 1.0$ & $1.0 \pm 0.2$ & $3.2 \pm 1.0$ & $3.9 \pm 1.5$ & $3.2 \pm 1.2$ & $0.9 \pm 0.3$ & $0.8 \pm 0.5$ & $2.8 \pm 1.1$ & $2.5 \pm 0.5$ & $3.6 \pm 1.3$ & $3.0 \pm 1.7$ & $2.7 \pm 1.2$ & $3.6 \pm 0.8$ & $4.7 \pm 1.3$ & 1.4 \\
\hline \multicolumn{18}{|c|}{2008} \\
\hline $\mathrm{PH}$ & $\mathrm{cm}$ & $28 \pm 5.3$ & $47 \pm 1.4$ & $44 \pm 4.1$ & $43 \pm 2.2$ & $45 \pm 3.8$ & $45 \pm 2.9$ & $45 \pm 4.1$ & $37 \pm 3.0$ & $42 \pm 3.8$ & $44 \pm 7.8$ & $43 \pm 4.9$ & $46 \pm 3.9$ & $45 \pm 6.3$ & $45 \pm 6.3$ & $46 \pm 3.8$ & 7.7 \\
\hline PBP & No. & $5.6 \pm 1.10$ & $4.6 \pm 1.10$ & $3.8 \pm 1.2$ & $5.6 \pm 0.9$ & $3.9 \pm 1.5$ & $2.7 \pm 1.7$ & $4.9 \pm 2.5$ & $3.7 \pm 1.1$ & $4.5 \pm 1.6$ & $4.1 \pm 1.3$ & $2.8 \pm 1.0$ & $5.2 \pm 1.4$ & $3.1 \pm 1.6$ & $2.4 \pm 1.4$ & $4.3 \pm 1.2$ & 2.4 \\
\hline NUP & No. & $12.9 \pm 5.4$ & $5.7 \pm 1.2$ & $5.3 \pm 1.7$ & $7.8 \pm 2.1$ & $5.1 \pm 1.7$ & $3.7 \pm 1.8$ & $7.8 \pm 5.0$ & $5.9 \pm 2.3$ & $5.9 \pm 1.8$ & $5.1 \pm 1.5$ & $3.8 \pm 1.0$ & $6.7 \pm 1.8$ & $4.1 \pm 1.6$ & $3.4 \pm 1.4$ & $5.6 \pm 1.6$ & 4.2 \\
\hline NFP & No. & $24 \pm 8.3$ & $42 \pm 15.4$ & $27 \pm 10.3$ & $79 \pm 39.6$ & $58 \pm 13.2$ & $45 \pm 21.9$ & $115 \pm 41.8$ & $19 \pm 7.5$ & $94 \pm 21$ & $73 \pm 23.7$ & $40 \pm 3.8$ & $112 \pm 30.9$ & $48 \pm 20.4$ & $33 \pm 16.7$ & $48 \pm 15.2$ & 67 \\
\hline FWP & $g$ & $0.05 \pm 0.01$ & $0.12 \pm 0.03$ & $0.07 \pm 0.03$ & $0.23 \pm 0.08$ & $0.17 \pm 0.05$ & $0.12 \pm 0.05$ & $0.32 \pm 0.07$ & $0.06 \pm 0.01$ & $0.26 \pm 0.02$ & $0.21 \pm 0.09$ & $0.11 \pm 0.05$ & $0.33 \pm 0.06$ & $0.15 \pm 0.01$ & $0.09 \pm 0.05$ & $0.13 \pm 0.06$ & 0.19 \\
\hline TFW & $\mathrm{g}$ & $1.82 \pm 0.11$ & $2.39 \pm 0.14$ & $2.36 \pm 0.08$ & $2.28 \pm 0.10$ & $2.42 \pm 0.10$ & $2.33 \pm 0.14$ & $2.48 \pm 0.28$ & $2.31 \pm 0.28$ & $2.46 \pm 0.28$ & $2.45 \pm 0.11$ & $2.61 \pm 0.17$ & $2.50 \pm 0.11$ & $2.51 \pm 0.14$ & $2.50 \pm 0.09$ & $2.64 \pm 0.12$ & 0.25 \\
\hline FY & dtha-1 & $1.5 \pm 0.6$ & $3.3 \pm 0.8$ & $1.5 \pm 0.5$ & $2.9 \pm 1.5$ & $4.1 \pm 1.7$ & $3.5 \pm 1.4$ & $2.1 \pm 1.8$ & $1 \pm 0.6$ & $4.6 \pm 2.6$ & $3.6 \pm 1.6$ & $3.7 \pm 0.9$ & $4.1 \pm 1.0$ & $4.3 \pm 1.6$ & $1.94 \pm 1.9$ & $3.4 \pm 1.4$ & 2.4 \\
\hline
\end{tabular}

Para $=$ parameter

Similar results were reported from Turkey where anise was sown in two different locations that had never been previously sown with anise, and very profuse disease development and fungal sporulation were seen. Disease severity had spread to approximately $90 \%$ at the end of the season (Erzurum et al., 2005). The number of fruits per plant is positively correlated with fruit weight per plant and fruit yield in both seasons (Tables 5 and 6). Significant differences regarding
TFW was observed among used accessions, ranging from 1.31 to $2.64 \mathrm{~g}$ in both years (Table 2). The significant variation between the accessions might be due to genetic characteristics. However, the accessions (1: 


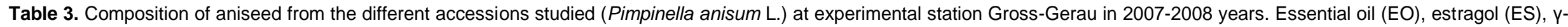
himachalene $(\mathrm{GH})$, and trans-anethole (TA)".

\begin{tabular}{|c|c|c|c|c|c|c|c|c|c|c|c|c|c|c|c|c|c|}
\hline \multicolumn{18}{|c|}{2007} \\
\hline Para. & Unit & 1 & 2 & 3 & 4 & 5 & 6 & 7 & 8 & 9 & 10 & 11 & 12 & 13 & 14 & 15 & LSD 5\% \\
\hline EO & $\%$ & $2.08 \pm 0.13$ & $2.95 \pm 0.11$ & $2.14 \pm 0.16$ & $2.30 \pm 0.07$ & $2.63 \pm 0.09$ & $2.27 \pm 0.16$ & $1.63 \pm 0.38$ & $2.43 \pm 0.22$ & $2.68 \pm 0.23$ & $2.58 \pm 0.21$ & $2.76 \pm 0.12$ & $2.54 \pm 0.10$ & $2.48 \pm 0.34$ & $2.67 \pm 0.20$ & $2.87 \pm 0.17$ & 0.27 \\
\hline ES & $\%$ & $0.9 \pm 0.07$ & $0.5 \pm 0.02$ & $1.3 \pm 0.12$ & $1.2 \pm 0.09$ & $0.6 \pm 0.05$ & $1.1 \pm 0.05$ & $1.6 \pm 0.15$ & $1.6 \pm 0.14$ & $0.6 \pm 0.03$ & $0.6 \pm 0.04$ & $0.6 \pm 0.04$ & $0.8 \pm 0.10$ & $0.6 \pm 0.06$ & $0.6 \pm 0.01$ & $0.6 \pm 0.02$ & 0.11 \\
\hline GH & $\%$ & $8.9 \pm 0.10$ & $8.2 \pm 0.44$ & $4.4 \pm 0.35$ & $7.9 \pm 0.46$ & $8.1 \pm 0.40$ & $8.0 \pm 0.55$ & $3.6 \pm 0.51$ & $6.1 \pm 0.14$ & $7.9 \pm 0.07$ & $7.3 \pm 0.35$ & $7.9 \pm 0.29$ & $6.3 \pm 0.72$ & $8.0 \pm 0.49$ & $7.6 \pm 0.58$ & $7.6 \pm 0.25$ & 1.0 \\
\hline TA & $\%$ & $82.9 \pm 0.42$ & $85.5 \pm 0.52$ & $90.3 \pm 0.39$ & $84.3 \pm 1.25$ & $85.8 \pm 0.60$ & $84.2 \pm 1.10$ & $90.9 \pm 1.20$ & $87.8 \pm 0.70$ & $85.8 \pm 0.27$ & $86.7 \pm 0.64$ & $85.8 \pm 0.53$ & $88.1 \pm 1.24$ & $85.4 \pm 0.86$ & $86.0 \pm 0.87$ & $86.2 \pm 0.37$ & 0.54 \\
\hline \multicolumn{18}{|c|}{2008} \\
\hline EO & $\%$ & $2.62 \pm 0.36$ & $2.59 \pm 0.17$ & $1.73 \pm 0.26$ & $2.08 \pm 0.20$ & $2.72 \pm 0.20$ & $2.66 \pm 0.19$ & $2.13 \pm 0.52$ & $1.72 \pm 0.20$ & $2.67 \pm 0.19$ & $2.49 \pm 0.07$ & $2.68 \pm 0.15$ & $2.58 \pm 0.10$ & $2.72 \pm 0.13$ & $2.63 \pm 0.06$ & $2.34 \pm 0.26$ & 0.39 \\
\hline ES & $\%$ & $0.73 \pm 0.05$ & $0.43 \pm 0.01$ & $0.86 \pm 0.09$ & $0.89 \pm 0.07$ & $0.39 \pm 0.02$ & $0.43 \pm 0.04$ & $1.1 \pm 0.08$ & $0.88 \pm 0.13$ & $0.45 \pm 0.04$ & $0.43 \pm 0.02$ & $0.42 \pm 0.02$ & $0.61 \pm 0.03$ & $0.45 \pm 0.01$ & $0.44 \pm 0.04$ & $0.41 \pm 0.02$ & 0.09 \\
\hline $\mathrm{GH}$ & $\%$ & $5.5 \pm 0.53$ & $5.0 \pm 0.12$ & $2.1 \pm 0.35$ & $4.2 \pm 0.18$ & $5.3 \pm 0.22$ & $4.9 \pm 0.30$ & $2.4 \pm 0.23$ & $2.6 \pm 0.54$ & $5.7 \pm 0.63$ & $5.3 \pm 0.17$ & $5.2 \pm 0.15$ & $4.4 \pm 0.29$ & $5.2 \pm 0.29$ & $5.4 \pm 0.35$ & $5.1 \pm 0.11$ & 0.6 \\
\hline TA & $\%$ & $90.5 \pm 1.19$ & $93.2 \pm 0.33$ & $95.7 \pm 0.71$ & $93.1 \pm 0.87$ & $92.3 \pm 0.33$ & $92.6 \pm 0.38$ & $95.5 \pm 0.56$ & $95.6 \pm 0.55$ & $91.7 \pm 1.29$ & $92.5 \pm 0.17$ & $92.3 \pm 0.29$ & $93.2 \pm 0.63$ & $92.3 \pm 0.49$ & $92.2 \pm 0.41$ & $92.8 \pm 0.26$ & 1.1 \\
\hline
\end{tabular}

15104614 Martin Bauer, and 8: Izmir Turkey) recorded the lowest TFW in both seasons and were more susceptible to $C$. malkoffii and are therefore regarded as poor plant establishment. It can be explained that, since fruit set depends on availability of sufficient nutrients while shifting from the vegetative to the reproductive stage, an increased level of infection resulted due to the limited availability of photosynthetic surface area, which reduced nutrients and water uptake and hence the size of individual fruit decreased and this, consequently, led to lower TFW of the anise. The correlations between TFW, fruit yield and essential oil content were negatively correlated in 2007 , contrary to that in 2008 , where a positive but weak relationship existed. It seems that an increase in fruit yield may result from an increase in fruit number, rather than an increase in individual fruit size.

\section{Fruit yield}

As the data shows in Table 2, there was great variation in fruit yield that ranged from 0.08 to 0.47 and 0.1 to $0.46 \mathrm{t} \mathrm{ha}^{-1}$ in 2007 and 2008 respectively. The highest fruit yields of 0.47 and $0.46 \mathrm{t} \mathrm{ha}^{-1}$ were produced by accessions 15 : HeilnB Aussaatrest 07 Landwirt Heil and 2: 15104893 Martin Bauer, respectively, in 2007 whereas the lowest yields were observed with accessions 1 : 15104614 Martin Bauer, 3: 16101709 Martin Bauer, 7: Hild and 8: Izmir Turkey in 2007. Accessions 5, 9, 12, 13 and 14 produced significantly higher fruit yields in 2008. The fruit yield variation reflects different genetic backgrounds of tested anise accessions in the current study. The lowest fruit yield was recorded in accessions 1 and 8, which might be due to a higher infection and lodging rate compared to other accessions. Lodging and fungal infection that occurs during the inflorescence or early fruit development infects all of the above parts of the plants, including leaves, flowers, stems and fruits, as well as limiting the photosynthetic surface area of anise plants that consequently leads to premature fruit formation and reduced individual fruit weight and size. Later, lodged anise plants cannot be easily harvested with a combine harvester, which reduces fruit quality.

\section{Essential oil content}

The essential oil content of the dried fruits of the 15 different accessions varied from 1.63 to 2.95 and 1.72 to $2.72 \%$ in 2007 and 2008 , respectively (Table 3). Current results are in accordance with previous studies that ranged from 2.66 to $2.73 \%$ in Turkey (Tuncturk and Yildirim, 2006). According to the EP, anise fruits intended for drug manufacture must have an essential oil concentration of more than 2\% (European Pharmacopoeia, 2000). In current trials, maximum oil contents were observed in accessions 2, 11, 15 and $5,11,13$ whereas the lowest concentration was observed in accessions 1, 3, 7 and 3, 4, 7 in 2007 and 2008, respectively (Table 3). Among all accessions, no. 1, 3 and 7 were more affected by C. malkoffii as well as by lodging in both seasons, which limited the number of ducts/cavities per fruit and led to a reduced capacity to accumulate oil compared with other accessions. The essential oil concentration showed remarkable variations among anise fruits from different origins (Tabanca et al., 2005; Tabanca et al., 2006). Orav et al. (2008) reported 
Table 4. Correlation coefficients for the relationships between the yield and quality parameters of anise at Gross-Gerau 2007

\begin{tabular}{|c|c|c|c|c|c|c|c|c|c|c|c|}
\hline Para. & PH & PBP & NUP & NFP & FWP & TFW & FY & EO & ES & TA & GH \\
\hline $\mathrm{PH}$ & - & 0.21 & 0.073 & -0.08 & -0.061 & $0.371^{* *}$ & $0.398^{* *}$ & $0.376^{\star \star}$ & $-0.533^{\star \star}$ & 0.197 & -0.023 \\
\hline PBP & - & - & $0.895^{\star *}$ & $0.380^{* \star}$ & 0.189 & 0.073 & $0.281^{*}$ & 0.136 & -0.249 & 0.11 & -0.027 \\
\hline UNP & - & - & - & $0.525^{\star *}$ & $0.321^{*}$ & 0.038 & $0.277^{\star}$ & 0.068 & -0.138 & 0.052 & -0.024 \\
\hline FNP & - & - & - & - & $0.767^{* *}$ & 0.037 & $0.604^{* *}$ & 0.184 & -0.141 & -0.191 & 0.193 \\
\hline FWP & - & - & - & - & - & 0.243 & $0.398^{* *}$ & 0.107 & -0.042 & -0.103 & 0.067 \\
\hline TFW & - & - & - & - & - & - & -0.017 & -0.244 & 0.154 & $0.462^{* *}$ & $-0.429^{* *}$ \\
\hline FY & - & - & - & - & - & - & - & $0.631^{* *}$ & $-0 . .629^{* *}$ & $-0.354^{* *}$ & $0.487^{* *}$ \\
\hline EO & - & - & - & - & - & - & - & - & $-0.658^{\star *}$ & $-0.317^{*}$ & $0.510^{* *}$ \\
\hline ES & - & - & - & - & - & - & - & - & - & $0.450^{* *}$ & $-0.657^{* *}$ \\
\hline TA & - & - & - & - & - & - & - & - & - & - & $-0.953^{* *}$ \\
\hline $\mathrm{GH}$ & - & - & - & - & - & - & - & - & - & - & - \\
\hline
\end{tabular}

${ }^{* *}$ correlation is significant at $\mathrm{p} 0.01,{ }^{*}$ correlation is significant at $\mathrm{p} 0.05$, plant height $(\mathrm{PH})$, primary branches per plant $(\mathrm{PBP})$, umbel number per plant (NUP), Fruit number per plant (NFP), Fruit weight per plant (FWP), 1000 -fruit weight (TFW), fruit yield $(F Y)$, essential oil (EO), estragol (ES), trans-anethole (TA) and $\mathrm{y}$-himachalene $(\mathrm{GH})$

Table 5. Correlation coefficients for the relationships between the yield and quality parameters of anise Gross-Gerau 2008.

\begin{tabular}{lccccccccccc}
\hline Para. & PH & PBP & UNP & FNP & FWP & TFW & FY & EO & ES & TA & GH \\
\hline PH & - & 0.188 & -0.204 & $0.387^{* *}$ & $0.433^{* *}$ & $0.521^{* *}$ & $0.662^{* *}$ & 0.084 & -0.219 & 0.115 & 0.03 \\
PBP & - & - & $0.840^{* *}$ & $0.666^{* *}$ & $0.664^{* *}$ & $-0.323^{*}$ & $0.334^{* *}$ & -0.04 & $0.361^{* *}$ & -0.152 & 0.02 \\
UNP & - & - & - & $0.468^{* *}$ & $0.435^{\star *}$ & $-0.563^{* *}$ & 0.053 & 0.031 & $0.441^{* *}$ & -0.25 & 0.017 \\
FNP & - & - & - & - & $0.991^{\star *}$ & 0.075 & $0.523^{* *}$ & 0.218 & 0.182 & -0.111 & 0.055 \\
FWP & - & - & - & - & - & 0.109 & $0.552^{* *}$ & 0.219 & 0.17 & -0.098 & 0.054 \\
TFW & - & - & - & - & - & - & $0.290^{*}$ & 0.131 & $-0.296^{*}$ & 0.211 & -0.019 \\
FY & - & - & - & - & - & - & - & $0.532^{* *}$ & $-0.464^{* *}$ & $-0.499^{* *}$ & $0.570^{* *}$ \\
EO & - & - & - & - & - & - & - & - & $-0.610^{* *}$ & $-0.726^{* *}$ & $0.743^{* *}$ \\
ES & - & - & - & - & - & - & - & - & - & $0.585^{* *}$ & $-0.795^{* *}$ \\
TA & - & - & - & - & - & - & - & - & - & - & $-0.931^{* *}$ \\
GH & - & - & - & - & - & - & - & - & - & - & - \\
\hline
\end{tabular}

${ }^{* *}$ correlation is significant at $\mathrm{p} 0.01$, *correlation is significant at $\mathrm{p} 0.05$, plant height $(\mathrm{PH})$, primary branches per plant (PBP), umbel number per plant (UNP), Fruit number per plant (FNP), Fruit weight per plant (FWP), 1000 -fruit weight (TFW), fruit yield $(\mathrm{FY})$, essential oil (EO), estragol (ES), trans-anethole (TA) and $y$-himachalene (GH).

that essential oil concentration varied from 1 to $5.4 \%$ for anise fruits from different European countries. Anise essential oil percentage depends not only on genetic resources, but also on the development of anise fruits. A significant change in essential oil accumulation was reported during the development of anise fruits with higher values of $5.5 \%$ at the waxy stage and $3.4 \%$ at the ripening stage (Omidbaigi et al., 2003). In the present study, essential oil contents were lower than at the waxy stage but comparable to that obtained at the ripening stage. It can be concluded from current and previous studies that anise plants should be harvested at the ripening stage in European countries, whereas harvesting at the waxy stage is recommended for tropical and subtropical regions due to higher air temperatures. In the current study, fruit yield was significantly correlated with essential oil $(r=0.631)$ and $(r=0.532)$ in 2007 and 2008, respectively.

\section{Chemical composition of essential oil}

In the current study, the essential oil was characterized by the occurrence of 20 different compounds, of which trans-anethole; $\mathrm{y}$-himachalene and estragol were the main compounds. The essential oil of anise fruits contains mainly phenylpropanoids and sesquiterpenoid hydrocarbons. It is of interest to note that the presence of trans-anethole, at more than $90 \%$, is present in very high quantities, which is distinctive of $P$. anisum L. A significant variation among used accessions was noticed regarding trans-anethole; $\gamma$-himachalene and estragol in 
Table 6. Essential oil composition (\%) of anise fruits (Pimpinella anisum L.) from different origins (countries).

\begin{tabular}{|c|c|c|c|c|c|c|c|c|c|c|c|c|c|c|c|c|}
\hline Compound & ${ }^{*} \mathrm{KI}$ & 1 & 2 & 3 & 4 & 5 & 6 & 7 & 8 & 9 & 10 & 11 & 12 & 13 & 14 & 15 \\
\hline Linalool & 1098 & 0 & 0 & 0.6 & 0.3 & 0 & 0 & 0 & 0 & 0 & 0 & 0 & 0 & 0 & 0 & 0 \\
\hline Estragol & 1197 & 1.1 & 0.7 & 1.0 & 1.2 & 0.6 & 0.7 & 1.3 & 0.5 & 0.5 & 0.4 & 0.4 & 0.5 & 0.3 & 0.4 & 0.3 \\
\hline Cis anethole & 1252 & 0.2 & 0.2 & 0.2 & 0.2 & 0.2 & 0.2 & 0.2 & 0.1 & 0.2 & 0.2 & 0.2 & 0.2 & 0.2 & 0.2 & 0.1 \\
\hline trans- & 1287 & 81.4 & 85.5 & 91.5 & 86 & 85 & 83.6 & 90.2 & 89 & 81.2 & 84.3 & 83.1 & 86.7 & 85.3 & 84.3 & 84.3 \\
\hline Elemene & 1333 & 0.4 & 0.3 & 0 & 0.3 & 0.3 & 0.3 & 0.1 & 0.1 & 0.5 & 0.3 & 0.3 & 0.2 & 0.3 & 0.3 & 0.3 \\
\hline Cyclc & 1367 & 0 & 0 & 0 & 0 & 0 & 0 & & 0 & 0 & & & & 0 & & 0.1 \\
\hline Beta elemen & 1388 & 0 & 0 & 0 & 0.1 & 0 & 0.1 & 0 & 0 & 0.1 & 0.1 & & 0.1 & 0.1 & 0.1 & 0 \\
\hline Metr & 1400 & 0 & 0 & 0 & 0.1 & 0 & & 0.1 & 0 & & & & & & & 0 \\
\hline a-hi & 1449 & 0.7 & 0.6 & 0.1 & 0.4 & 0.6 & 0.6 & 0.2 & 0.3 & 0.8 & 0 & 6 & & 0.6 & 0.6 & 0.6 \\
\hline & 1478 & 7.2 & 6.0 & 1.9 & 4.7 & 6.2 & 6.2 & 2.3 & 3.3 & 7.9 & & & 9 & 8 & 6.4 & 5.6 \\
\hline$\alpha-a r$ & 1482 & 0.2 & 0.2 & 0 & 0.1 & 0.1 & 0.1 & 0 & 0.1 & 0.1 & 0.1 & .2 & .1 & 1 & 0.1 & 0.1 \\
\hline isoeugenol & 1489 & 0.1 & 0.2 & 0.2 & 0.3 & 0.2 & 0.2 & 0.2 & 0.3 & 0.2 & 0.2 & 0.2 & .1 & 0.2 & 0.2 & 0.2 \\
\hline$\alpha$-zin & 1493 & 1.3 & 0.5 & 0.2 & 0.6 & 0.6 & 0.6 & 0.3 & 0.4 & 0.8 & 0.5 & 0.6 & 0.5 & 0.5 & 0.6 & 0.6 \\
\hline$\beta$-him & 1499 & 0.4 & 0.4 & 0.1 & 0.3 & 0.4 & 0.4 & 0.1 & 0.2 & 0.5 & 0.4 & 0.4 & 0.3 & 0.3 & 0.4 & 0.3 \\
\hline a-mu & 1502 & 0.1 & 0.1 & 0 & 0.1 & 0.1 & 0.1 & 0 & 0 & 0.1 & 0.1 & 0.1 & 0.1 & 0.1 & 0.1 & 0.1 \\
\hline$\beta$-bisa & 1506 & 0.9 & 0.2 & 0.1 & 0.3 & 0.3 & 0.2 & 0.2 & 0.3 & 0.4 & 0.2 & 0.3 & 0.2 & 0.2 & 0.3 & 0.3 \\
\hline$\beta$-se & 1522 & 0.2 & 0 & 0 & 0 & 0 & 0.1 & 0 & 0 & 0 & 0 & 0.1 & 0 & 0 & 0 & 0.1 \\
\hline Spat & 1580 & 0.2 & 0.1 & 0 & 0 & & & 0 & 0.1 & & & & 0.1 & ( & 0.1 & 0.1 \\
\hline & 162 & 0 & 0 & 0 & 0 & 0 & & 0 & 0. & 0 & 0. & & 0 & 0 & 0 & 0.1 \\
\hline Unknov & 1831 & 4.8 & 4.5 & 3.7 & 4.5 & 4.8 & 5. & 4.3 & 4.8 & 5.9 & 5. & & 5 & 5.3 & 5.1 & 5.9 \\
\hline Unkno & 1886 & 0.8 & 0.5 & 0.3 & 0.5 & 0.6 & 0.8 & 0.4 & 0.5 & 0.9 & 0.8 & 0 . & 0.6 & 0.6 & 0.6 & 0.7 \\
\hline Unknov & 2109 & 0 & 0 & 0 & 0 & 0 & 0 & 0 & 0 & 0 & 0 & 0.7 & 0 & 0 & 0 & 0 \\
\hline Mean & - & 100 & 99.9 & 100 & 100 & 100 & 100 & 100 & 100 & 100 & 100 & 100 & 100 & 100 & 100 & 100 \\
\hline Total compound & - & 16 & 15 & 12 & 17 & 15 & 18 & 13 & 15 & 15 & 17 & 20 & 17 & 15 & 17 & 18 \\
\hline
\end{tabular}

${ }^{*} \mathrm{KI}$ : Kovat's retention index.

both years. The major constituent in the essential oil of tested accession fruits were found to be a phenylpropanoid, namely trans-anethole, which ranged from 82.9 to 90.9 and 90.5 to 95.7 in 2007 and 2008, respectively, which is in accordance with previous studies (Orav et al., 2008; Yan et al., 2011). A higher concentration of trans-anethole was observed in 2008 compared with 2007. Variation in the composition of anise due to genetic and environmental factors has been previously reported in several studies (Orav et al., 2008; Yan et al., 2011).

Orav et al. (2008) obtained anise fruits from different retail pharmacies from different European countries, of which a maximum concentration of trans-anethole was recorded in fruit samples named Germany1 (92.2\%) and Germany2 $(93.7 \%)$ and a minimum was obtained from France $(76.9 \%)$. The highest levels of trans-anethole were noted in accessions 3,7 , and 8 , and were regarded as sweeter accessions that possessed potential as an additive in food items. The higher concentration of transanethole in these accessions might be due to the fungal infection caused by C. malkoffii. Environmental stresses, such as pathogen attack, UV-irradiation, high light impact, wounding, nutrient deficiencies, temperature and herbicide treatment often increase the accumulation of phenylpropanoids (Dixon and Paiva, 1995). Sander and Heitefuss (1998) conducted experiments with wheat and reported that, in response to infection with a compatible race of powdery mildew (Erysiphe graminis f.sp tritici), levels of phenolic acids slightly increased in leaves of the cutlivar Syros grown with low and medium nitrogen supply. It can be concluded from current results that phenylpropanoids are also synthesized in a similar way as phenolic compounds and can be increased under stress conditions.

It can be supposed that activity of phenylalanine ammonia-lyase (PAL) enzyme, which is responsible for the synthesis for phenolic and phenylpropanoids compounds, increased with fungal infection. Fungal invasion triggers the transcription of messenger RNA that code for PAL, thus enhancing the amount of PAL in the plant, which then stimulates the synthesis of phenolic compounds (Logemann et al., 1995; Taiz and Zeiger, 2002). It can be assumed that phenylpropanoids and phenolic compound concentrations increase when plants face stressful conditions. According to the EP, anise essential oil must have a trans-anethole concentration between 84 to $93 \%$. Current studied accessions fulfill this requirement and are characterized as good chemotypes of anise. There was a significant but negative relationship 
( $r=0.953$ in 2007, $r=0.931$ in 2008) evident between trans-anethole and $y$-himachalene. Fifteen accessions of anise were evaluated in the present study, which revealed significant differences regarding $y$-himachalene and estragol in both seasons. Estragol (methylchevicol), the flavoring agent, is considered to have a negative impact on animal and was deleted from the list of flavors in food stuffs (Burt, 2004). The concentration of $\mathrm{Y}$ himachalene and estragol ranged from 2.1 to 8.9 and 0.4 to 1.6 in 2007 and 2008, respectively (Table 3). However, the accessions $1,2,4,5,6,9,10,11,13,14$ and 15 showed higher levels of $\mathrm{y}$-himachalene with lower amounts of estragol, which are regarded as sweeter accessions that can be used in food products. From current results, it can be concluded that, with increased trans-anethole concentration, $\mathrm{Y}$-himachalene concentration decreased in 2008. The EP limit of estragol in anise essential oil ( 0.5 to $6.0 \%$ ) was not exceeded in the investigated samples.

Orav et al. (2008) analyzed anise fruits from various European countries. Samples were collected from Germany, named as Germany1 and Germany2, which contained 2.0 and $2.3 \%$ estragol and 1.4 and $0.4 \% \mathrm{y}^{-}$ himachalene, respectively. The lower concentration of $\mathrm{y}^{-}$ himachalene in a previous study might be due to longer storing conditions, since the author obtained anise fruits from retail pharmacies and the prolonged elapsed time since harvesting caused oxidation of anise components. In comparison to earlier studies, the values of estragol in the present results were not higher than the values reported by Askari et al. (1998) (1.04\%), Rodrigues et al. (2003) (0.9 to $1.5 \%)$, Özcan and Chalchat (2006) (2.4\%) and Orav et al. (2008) (0.5 to 2.3\%). A significant correlation was noticed between estragol and transanethole in both seasons.

The minor constituents in the oil of the anise accessions from this present trial were similar to those found in previous studies, with components including, linalool $(0.6 \%)$, a-himachalene $(0.1$ to $0.9 \%)$, cis-anethole ( 0.1 to $0.2 \%)$, elemene delta ( 0.1 to $0.5 \%)$, cyclosativene ( 0 to $0.1 \%)$, beta-elemene ( 0 to $0.1 \%)$, methyleugenol $(0$ to $0.1 \%)$, methylisoeugenol $(0.1$ to $0.3 \%), \quad \beta$ sesquiphellandrene $(0.1$ to $0.2 \%)$, spathulenol $(0.1$ to $0.2 \%)$, $\alpha$-amorphane $(0.1$ to $0.2 \%)$, $\alpha$-zingiberene $(0.2$ to $1.3 \%), \beta$-himachalene $(0.1$ to $0.5 \%)$, $\alpha$-muurolene $(0$ to human health and $0.1 \%)$ and $\beta$-bisabolene $(0.1$ to $0.9 \%)$ (Arslan et al., 2004; Orav et al., 2008; Yan et al., 2011). According to the EP, the commercial anise oil should contain linalool and cis-anethole within the range of 0.1 to 1.5 and $0.5 \%$, respectively. The EP limits of these components were not exceeded in the evaluated accessions.

\section{Conclusion}

The accessions were different in their oil content constituents, morphological traits, and yield contributing parameters. Furthermore, they reflected an excellent range of genetic diversity of the anise crop and signify its suitability for multi-dimensional industrial uses. Current results showed that accessions 1 and 8 were more susceptible to fungal infection, which reduced fruit yield due to considerable losses in secondary inflorescence. All accessions used in the current trials resulted in a high quality essential oil component. These essential oil constituents meet the requirement of the European pharmacopeia with more than $90 \%$ trans-anethole and less than $1 \%$ estragol, which characterizes a good anise chemotype. In addition to the good quality essential oil, some of the accessions like Heil-B Aussaatrest 07 Landwirt Heil and 2: 15104893 Martin Bauer produced higher fruit yield, and therefore could be used at the commercial level in Germany.

\section{ACKNOWLEDGMENTS}

The authors are thankful to Higher Education Commission (HEC) Pakistan and German Academic Exchange Service (DAAD) for financial support to complete this project. Technical assistance provided by Mr. Bernhard Hormann, Pia Doernfeld, Rosa Allerdings and precious suggestion of Dr. Feng Yan are also worth mentioning.

\section{REFERENCES}

Adams RP (1995). Identification of essential oil components by gas chromatography-mass spectrometry, Allured Pub. Crop. Illinois. pp. 69-351.

Arslan N, Gürbüz B, Sarihan EO, Bayrak A, Gümüscü A (2004). Variation in essential oil content and composition in Turkish anise (Pimpinella anisum L.) populations. Turk. J. Agri. For. 28:173-177.

Askari F, Sefidkon F, Mirza M (1998). Quantitative and qualitative study of components in essential oil of Pimpinella anisum L. Res. Recon. 38:70-77.

Awad NM, Turky AS, Mazhar AA (2005). Effects of bio- and chemical nitrogenous fertilizers on yield of anise (Pimpinella anisum L.) and biological activities of soil irrigated with agricultural drainage water. Egypt J. Soil Sci. 45:265-278.

Bown D (2001). Encyclopedia of Herbs and their Uses. The Herb Society of America. Darling, Kindersley, London P. 440.

Burt S (2004). Essential oils, their antibacterial properties and potential applications in foods - a review. Int. J. Food Microbiol. 94:223-253.

Dixon RA, Paiva NL (1995). Stress-induced phenylpropanoid metabolism. Plant Cell 7:1085-1097.

Ebert K (1982). Medicinal and aromatic plants, Scientific Publishers, Stuttgart. pp. 53-54.

Erzurum K, Demirci F, Karakaya A, Cakir E, Tuncer G, Maden S (2005). Passalora blight of anise (Pimpinella anisum) and it's Control in Turkey. Phytoparasitica 33:261-266.

European Pharmacopoeia (2000). Dritter Nachtrag, Council of Europe, Strasbourg. 3:499-500.

Gülcin I, Oktay M, Kirecci E, Küfrevioglu Öll (2003). Screening of antioxidant and antimicrobial activities of anise (Pimpinella anisum L.) seed extracts. Food Chem. 83:371-382.

Hänsel R, Sticher O, Steinegger E (1999). Pharmakognosiephytopharmaize. 6. Auflage. Springer-Verlag, Berlin, Heidelberg. pp. 692-695. 
Heeger EF (1956). Handbuch des Arznei-und Gewürzpflanzenbaues. Deutscher Bauernverlag. pp. 578-583.

Knio KM, Usta J, Dagher S, Zournajian H, Kreydiyyeh S (2008). Larvicidal activity of essential oils extracted from commonly used herbs in Lebanon against the seaside mosquito, Ochlerotatus caspius. Biores. Technol. 99:763-768.

Kosalec I, Pepelinjak S, Kustrak D (2005). Antifungal activity of fluid extract and essential oil from anise fruits (Pimpinella anisum L., Apiaceae). Acta Pharm. 55:377-385.

Logemann E, Parniske M, Hahlbrock K (1995). Modes of expression and common structural features of the complete phenylalanine ammonialyase gene family in parsley. USA. Proc. Natl. Acad. Sci. 92:59055909.

Maheshwari SK, Gangrade SK, Trivedi KC (1989). Effect of date and method of sowing on grain and oil yield and oil quality of anise. Indian perfumer 33:169-173.

Omidbaigi R (2000). Production and Processing of Medicinal Plants. 3:26-36.

Omidbaigi R, Hadjiakhoondi A, Saharkhiz M (2003). Changes in content and chemical composition of (Pimpinella anisum) oil at various harvest time. J. Essent. oil Bear PI. 6:46-50.

Orav A, Raal A, Arak E (2008). Essential oil composition of Pimpinella anisum $\mathrm{L}$. fruits from various European countries. Nat. product Res. 22:227-232.

Özcan MM, Chalchat JC (2006). Chemical composition and antifungal effect of anise (Pimpinella anisum L.) fruit oil at ripening stage. Ann. Microbiol. 56:353-358.

Poss E (1991). Studies on the influence of a seed treatment on germination of selected medicinal and Spice plant species, Thesis, Technical University Munich-Weihenstephan.

Reineccius G (1994). Source book of flavours. 2nd ed. Chapman and Hall. New York. pp. 353-357.

Rodrigues VM, Rosa PTV, Marques MOM, Petenale AS, Meireles MAA (2003). Supercriticial extraction of essential oil from aniseed (Pimpinella anisum) using $\mathrm{CO}_{2}$ solubility, kinetics and composition data. J. Agric. Food Chem. 51:1518-1523.

Ross IA (2001). Medicinal Plants of the World: Chemical Constitutes, Traditional and Modern Medicinal Uses. Humana press, Totowa, New Jersey. 2:363-374.

Sander JF, Heitefuss R (1998). Susceptibility to Erysiphe graminis f. sp. tritici and phenolic acid content of wheat as influenced by different levels of nitrogen fertilization. J. Phytopathol. 146:495-507.

Shukla HS, Tripathi SC (1987). Antifungal substance in the essential oil of anise (Pimpinella anisum L.). Agric. Boil. Chem. 51:1991-1993.
Simon JE, Chadwick AF, Craker LE (1984). Herbs: an indexed bibliography. 1971-1980. the scientific literature on selected herbs, and aromatic and medicinal plants of the temperate zone. Archon Books, Hamden, CT. P. 770.

Tabanca N, Demirci B, Kirimer N, Baser KHC, Bedir E, Khan IA, Wedge DE (2005). Gas chromatographic-mass spectrometric analysis of essential oil from Pimpinella aurea, Pimpinella corymbosa, Pimpinella peregrina and Pimpinella puberula gathered from Eastern and Southern. Turk. J. Chromatogr. 1097:192-198.

Tabanca N, Demirci B, Ozek T, Kirimer N, Baser KHC, Bedir E, Khan IA, Wedge DE (2006). Gas chromatographic-Mass spectrometric analysis of essential oil from Pimpinella species gathered from Central and Northern turkey. J. Chromatogr. A. 1117:194-205.

Taiz T, Zeiger E (2002). Plant physioliogy 3rd edn. Secondary metabolites and plant defense. pp. 283-308.

Tunc I, Sahinkaya S (1998). Sensitivity of two greenhouse pests to vapours of essential oils. Entomologia Experimentalis et Applicata 86:183-187.

Tuncturk M, Yildirim B (2006). Effect of seed rates on yield and yield components of anise (Pimpinella anisum L.). Indian J. Agric. Sci. 76:679-681.

Ullah H, Honermeier B (2013). Fruit yield, essential oil concentration and composition of three anise cultivars (Pimpinella anisum L.) in relation to sowing date, sowing rate and locations, Industrial Crops and Products. 42:489-499.

Yan F, Beyer EM, Azizi A, Honermeier B (2011). Effect of sowing time and sowing density on fruit yield, essential oil concentration and composition of anise (Pimpinella anisum L.) under field conditions in Germany. J. Med. Spice Plants 16:26-33.

Zehtab-salmasi S, Javanshir A, Omidbaigi R, Alyari H, Ghassemigolezani K (2001). Effects of water supply and sowing date on performance and essential oil production of anise (Pimpinella anisum L.). Acta Agron. Hungarica 49:75-81.

Zheljazkov VD, Callahan A, Cantrell CL (2008). Yield and oil composition of 38 basil (Ocimumbasilicum L.) . Accessions Grown in Mississippi. J. Agric. Food Chem. 56:241-245. 